\title{
Renin Gene Polymorphisms in Bangladeshi Hypertensive Population
}

\author{
Rownock Afruzaㄹ, Laila N Islam¹, Sajal Banerjee², Md. Mahbub Hassan³, Fumiaki Suzuki", AHM Nurun \\ $\mathrm{Nabi}^{1}{ }^{\bowtie}$ \\ 1. Department of Biochemistry and Molecular Biology, University of Dhaka, Dhaka-1000; \\ 2. Department of Cardiology, Bangabandhu Sheikh Mujib Medical University; \\ 3. Laboratory Medicine Division, Apollo Hospitals, Dhaka, Bangladesh; \\ 4. Laboratory of Animal Biochemistry, Faculty of Applied Biological Sciences, Gifu University, Japan.
}

$\triangle$ Corresponding author: AHM Nurun Nabi, PhD. Associate Professor, Department of Biochemistry and Molecular Biology, University of Dhaka, Dhaka-1000, Bangladesh. Tel: 880-2-9661900/7660 E-mail: nabi@du.ac.bd.

(C) Ivyspring International Publisher. This is an open-access article distributed under the terms of the Creative Commons License (http://creativecommons.org/ licenses/by-nc-nd/3.0/). Reproduction is permitted for personal, noncommercial use, provided that the article is in whole, unmodified, and properly cited.

Published: 2014.02.01

\begin{abstract}
Objective: Linkages of renin gene polymorphisms with hypertension have been implicated in several populations with contrasting results. Present study aims to assess the pattern of renin gene polymorphisms in Bangladeshi hypertensive individuals.

Methodology: Introns I, 9 of renin gene and 4063 bases upstream of promoter sequence of renin gene were amplified from the genomic DNA of the total 124 (hypertensive and normotensive) subjects using respective primers. Polymerase chain reaction-based restriction fragment length polymorphisms were performed using Bgll, Mbol and Taql restriction enzymes.

Results: Homozygosity was common in renin gene regarding $B g l l(b b=48.4 \%, B b=37.9 \%$, $\left.\mathrm{BB}=13.7 \%, \chi^{2}=1.91, \mathrm{P}>0.05\right)$, Taql $\left(\mathrm{TT}=81.5 \%, \mathrm{Tt}=14.5 \%, \mathrm{tt}=4.0 \%, \chi^{2}=7.50, \mathrm{P}<0.0 \mathrm{I}\right)$ and $\mathrm{Mbol}$ $\left(\mathrm{mm}=63.7 \%, \mathrm{Mm}=32.3 \%, \mathrm{MM}=4.0 \%, \chi^{2}=0.00, \mathrm{P}>0.05\right)$ polymorphisms among total study population. For Bgll and Taql genotype distribution, hypertensive subjects (Bgll: $\chi^{2}=6.66, \mathrm{P}<0.05 ;$ Taql: $\chi^{2}$ $=10.28, P<0.005)$ significantly deviate from Hardy-Weinberg Equilibrium law compared to normotensive subjects (Bgll: $\chi^{2}=0.5 \mathrm{I}, \mathrm{P}>0.05 ;$ Taql: $\chi^{2}=0.20, \mathrm{P}>0.05$ ). On the other hand, with respect to Mbol polymorphisms of renin gene, only normotensive subjects deviate from the law (patients: $\chi^{2}=1.28, P>0.05$; vs controls: $\chi^{2}=6.81, P<0.01$ ). In the context of allelic frequency, common T allele was clearly prevalent ( $T$ frequency $=0.86, t$ frequency $=0.14$ ) for Taql, but rare alleles $b$ and $m$ were more frequent for both $B g l l(b$ frequency $=0.69, B$ frequency $=0.3 \mathrm{I})$ and $\mathrm{Mbol}(\mathrm{m}$ frequency $=0.80 \mathrm{M}$ frequency $=0.20$ ) polymorphisms, respectively.

Conclusion: Thus, we report that Bangladeshi hypertensive subjects did not show any distinct pattern of renin gene polymorphisms compared to their healthy control subjects with regard to their genotypic and allelic frequencies.
\end{abstract}

Key words: Renin gene polymorphism, genetic variation, hypertension, renin, BglI polymorphism, TaqI polymorphism, MboI polymorphism, association analysis, Hardy-Weinberg equilibrium.

\section{Introduction}

Hypertension is a complex multifactorial disorder with genetic, environmental and demographic factors contributing to its prevalence [1]. Studies have shown that about $90-95 \%$ of cases are primary hy- 
pertension, with high blood pressure and without recognizable or explicable risk factors [2]. Hypertension is related to high blood pressure which is one of the contributing factors for the onset of macrovascular complications such as myocardial infarction, stroke and end-stage renal disease. Components of the renin-angiotensin-aldosterone system (RAAS) are the important factors that regulate body's blood pressure homeostasis and dysfunction of this system leads to hypertensive phenotypes [3-5]. There are also several associated causes responsible for the instigation of high blood pressure for example, age, obesity and factors like alcohol consumption, smoking [6-8]. However, genetic factors also account for the initiation of variable ranges of high blood pressure in different populations. Also, genes of RAAS are of particular interest to find out the gene loci associated with hypertension. Among them, renin has always got top priority for being the key enzyme [9-11].

Animal model studies have clearly demonstrated that development of hypertension is associated with the variations in blood pressure controlling renin gene [12]. To find out an association of genetic predisposition with hypertension in human, several polymorphisms within renin gene or near its promoter sequences have been reported with inconsistent results [13-16]. BglI dimorphism [15] and BglI B allele in renin gene [17] was found to be associated with increased risk of developing essential hypertension, while Naftilan et al. [14] did not find such relationship. Study with Chinese population revealed that hypertension is more strongly associated with HindIII polymorphisms of renin gene than BglI [18]. Another study conducted among the rural residents of Beijing, China and urban Tibetan individuals confirmed that prevalence of hypertension is related to TaqI polymorphisms of $4063 \mathrm{bp}$ upstream of renin gene promoter [19]. Moreover, $\mathrm{MboI}$ dimorphism in intron 9 of the human renin gene is strongly associated with essential hypertension [20].

Developing countries are more likely to face burden of chronic non-communicable diseases in near future due to increased life expectancy as well as demographic transition [21]. Of these diseases, hypertension is one of the most important threatable causes of mortality and morbidity in the elderly population [21]. On the other hand, representative data on the prevalence of hypertension in a Bangladeshi population are insufficient. A study reported that prevalence of hypertension in adults is $11.3 \%$ in Dhaka only [22]. Further, migrant Bangladeshis had greater risk for hypertension compared to the Europeans and other migrant South Asians [23]. It is important to reveal the molecular mechanism of blood pressure regulation. This will help in pharmacological aspects concerning the fundamental gene therapy based specific treatment to the needs of the patient. However, studies on the possible genetic predisposition to hypertension among Bangladeshi population in the context of renin gene polymorphisms are lacking. Thus, the objectives of this study was to investigate the pattern of renin gene polymorphism among the Bangladeshi hypertensive and normotensive subjects by analyzing the PCR-based BglI, TaqI and MboI restriction fragment length polymorphisms.

\section{Methods and Materials}

\section{Study subjects and collection of blood samples}

A total of 66 hypertensive unrelated Bangladeshi individuals who attended in the outdoor of the cardiology department of Bangabandhu Sheikh Mujib Medical University (BSMMU) and Appollo hospitals, Dhaka were enrolled in this study. Control subjects (n $=58$ ) such as university and hospital personnels, office staffs and post-doc fellows willingly donated their blood for the study. The study was conducted according to the guidelines set by the ethical review board of the faculty of Biological Science, University of Dhaka. Blood pressure of each individual was measured at sitting position. People having systolic blood pressure (SBP) $\geq 140 \mathrm{mmHg}$ and diastolic blood pressure $(\mathrm{DBP}) \geq 90 \mathrm{mmHg}$ (according to World Health Organization) were considered as the hypertensive subjects. Status of the patients or grading of hypertension considering the severity of patients was not taken into consideration in the study. Patients with diabetes, chronic kidney disease or any other major renal diseases, hepatitis B virus surface antigen (HbsAg) positive were excluded from this study. The control subjects had no major health complications. Five to six milliliter of blood was collected from each individual. Plasma samples were used to analyze total cholesterol using standard enzymatic-colorimetric methods.

\section{Rationale behind choosing Bgll, Mbol and Taql restriction sites}

The human renin gene consists of 10 exons and 9 introns [24]. The $B g l \mathrm{I}$ and $\mathrm{MboI}$ restriction sites are present at the first and ninth introns of renin gene, respectively and TaqI restriction site is present at the 4063 bases upstream of the promoter sequence. Variation in these sites, especially in BglI and TaqI, (considered to be the transcription factor binding sites) could affect the functional association of renin gene with fluid homeostasis i.e., blood pressure leading to hypertension. Besides, different literatures regarding the association of renin gene polymorphisms with hypertension among Asians, Europeans and Ameri- 
cans have indicated that almost all of the studies have been carried out giving emphasis on $\mathrm{BglI}, \mathrm{MboI}$ and TaqI restriction fragment renin gene polymorphisms. Though some of them found strong association between polymorphism and hypertension, however, many of them did not. As this is the first study on renin gene polymorphism among Bangladeshi population, we were also interested concerning $B g l \mathrm{I}, \mathrm{MboI}$ and $\mathrm{TaqI}$ restriction sites present in renin gene to observe their association with hypertension.

\section{Extraction of genomic DNA}

Genomic DNA was extracted by organic extraction procedure from cellular fraction of blood [25]. The quantity and level of purification of extracted DNA was measured using NanoDrop (NanoDrop1000, US). The average concentration of extracted DNA was $357 \pm 17.88 \mathrm{ng} / \mu \mathrm{L}$. This method generates purified DNA with an average value of $260 / 280$ ratio was 1.79 and of $260 / 230$ ratio was 1.57 in case of total study subjects. Extracted DNA samples were subjected to agarose gel electrophoresis to determine the quality of DNA and band in Fig. 1a and $1 \mathrm{~b}$ did not show any variation.

\section{Polymerase chain reaction and restriction di- gestion of PCR products}

To perform polymerase chain reactions, $50 \mu \mathrm{L}$ of reaction mixture was prepared using $10 \mathrm{mM}$ dNTPs, $100 \mu \mathrm{M}$ of forward and reverses primer (specific for

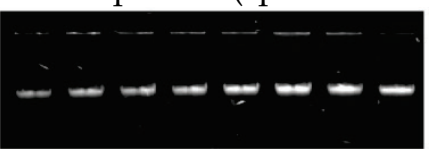

(a)

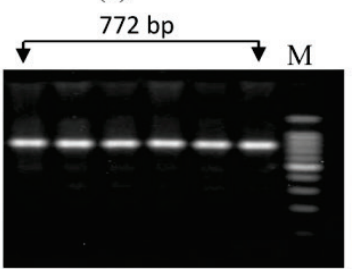

(c)

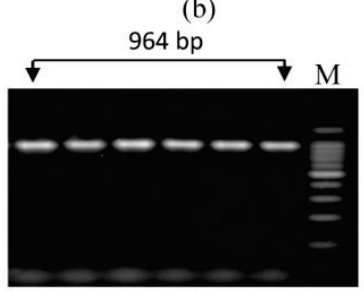

(d)

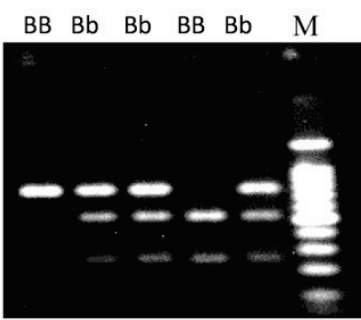

(f)

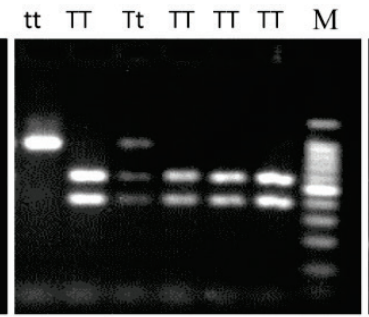

(g) renin gene) and 1000 Unit of Taq DNA polymerase. PCR conditions applied for the amplification of respective regions have been presented in Table 1. PCR products were subjected to restriction digestion using $B g l$ I, TaqI and MboI according to the manufacturer's recommended protocol with minor modifications. Briefly, $2.0 \mu \mathrm{L}$ restriction enzyme buffer (10X buffer), $0.4 \mu \mathrm{L}$ bovine serum albumin $(10 \mu \mathrm{g} / \mu \mathrm{L}), 0.6 \mu \mathrm{L}$ restriction enzyme (1000 Unit), $7 \mu \mathrm{L}$ deionized water and $10 \mu \mathrm{L}$ of PCR product $(1 \mu \mathrm{g} / \mu \mathrm{L})$ were mixed gently and incubated for 2 hours at $37^{\circ} \mathrm{C}$ for restriction digestion by $\mathrm{BglI}$ and $\mathrm{MboI}$ and, $65^{\circ} \mathrm{C}$ for TaqI digestion. Digested products were evaluated by agarose gel electrophoresis using $100 \mathrm{bp}$ ladder as standard.

\section{Data analyses}

The results were expressed as mean $( \pm S D)$ and to compare the differences between different variables from the control and hypertensive subjects, independent Student's t-test was performed. Multivariate analyses were also performed using different parameters as independent variables (e.g., age, gender, SBP, DBP) to find out their association with genotypic variations of renin gene. A $p$ value of less than 0.05 was considered significant. Allele frequencies were determined by Hardy-Weinberg equilibrium calculator using the method developed by Rodriguez et al. [26].

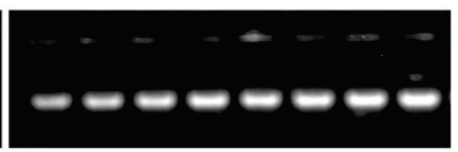

(b)

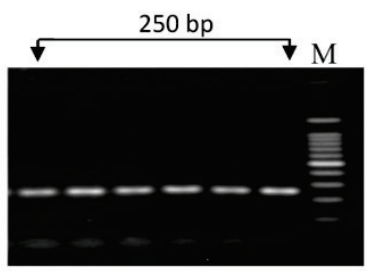

(e)

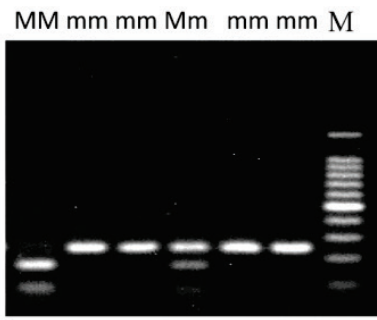

(h)

Figure I. Agarose gel electrophoresis showing the genomic DNA and PCR products of renin gene having different polymorphisms. Figures a and b represent the genomic DNA extracted from both control and patient subjects, respectively. Figures $c, d$ and e represent PCR products containing Bgll, Taql and $\mathrm{Mbol}$ polymorphisms of renin gene. Figures $\mathrm{f}, \mathrm{g}$ and $\mathrm{h}$ represent the restriction digestion products of amplified region using $\mathrm{Bgll}, \mathrm{Taql}$ and $\mathrm{Mbol}$ restriction enzymes respectively. Here, BB, Bb and bb; TT, Tt and tt; and MM, Mm and mm represent three different genotypes of Bgll, Taql and Mbol RFLP of renin gene; $M$ (marker) represents 100 bp ladders. In case of Bgll polymorphism, size of digested PCR products are 515 bp and 257 bp; for Taql polymorphism these are 570 bp and 394 bp; for Mbol polymorphism these are 171 bp and 79 bp. 
Table I. Conditions applied to perform polymerase chain reaction for the determination of different polymorphisms of renin gene.

\begin{tabular}{|c|c|c|c|}
\hline Sequence site in renin gene & $\begin{array}{l}\text { Primer sequences } \\
\text { Forward primer (FP) \& Reverse primer (RP) }\end{array}$ & PCR conditions & $\begin{array}{l}\text { Size of PCR } \\
\text { products (bp) }\end{array}$ \\
\hline $\begin{array}{l}4063 \text { bases upstream of start codon of } \\
\text { renin gene }\end{array}$ & $\begin{array}{l}\text { FP: 5'GCTGTCTTCTGGTGGTACTGCC3' } \\
\text { RP:5'TGCTGGCCATGAACTGGTTCTAGC3' }\end{array}$ & $\begin{array}{l}95^{\circ} \mathrm{C}-5 \mathrm{~m}\left(95^{\circ} \mathrm{C}-45 \mathrm{~s} 60^{\circ} \mathrm{C}-30 \mathrm{~s}\right. \\
\left.72^{\circ} \mathrm{C}-1 \mathrm{~m} 30 \mathrm{~s}\right) \times 3072^{\circ} \mathrm{C}-6 \mathrm{~m}\end{array}$ & 964 \\
\hline within intron 1 of renin gene & $\begin{array}{l}\text { FP:5'GGGGAAGCAGCTTGATATCGTGG3' } \\
\text { RP: 5'CTAGGCTGGAGCTCAAGCGATC3' }\end{array}$ & $\begin{array}{l}95^{\circ} \mathrm{C}-5 \mathrm{~m}\left(92^{\circ} \mathrm{C}-30 \mathrm{~s} 60^{\circ} \mathrm{C}-30 \mathrm{~s}\right. \\
\left.72^{\circ} \mathrm{C}-30 \mathrm{~s}\right) \times 3072^{\circ} \mathrm{C}-4 \mathrm{~m}\end{array}$ & 772 \\
\hline within intron 9 of renin gene & $\begin{array}{l}\text { FP: 5'GAGGTTCGAGTCGGCCCCCT3' } \\
\text { RP: 5'TGCCCAAACATGGCCACACAT3' }\end{array}$ & $\begin{array}{l}94^{\circ} \mathrm{C}-5 \mathrm{~m}\left(94^{\circ} \mathrm{C}-30 \mathrm{~s} 68^{\circ} \mathrm{C}-30 \mathrm{~s}\right. \\
\left.72^{\circ} \mathrm{C}-30 \mathrm{~s} 72^{\circ} \mathrm{C}-5 \mathrm{~m}\right) \times 30\end{array}$ & 250 \\
\hline
\end{tabular}

\section{Results}

\section{Anthropometric data of the study subjects}

The anthropometric and biochemical details of the study subjects are presented in Table 2 . The mean systolic blood pressure (SBP) and diastolic blood pressure (DBP) were significantly higher $(P<0.001)$ in the hypertensive $(150.5 \pm 15.8$ and $94.0 \pm 13.9 \mathrm{mmHg}$, respectively) compared to that of the normotensive subjects (115.0 \pm 5.5 and $77.2 \pm 4.5 \mathrm{mmHg}$, respectively). The levels of total plasma cholesterol, random blood glucose, plasma creatinine and total protein of the normotensive and hypertensive subjects were $166.8 \pm 38.1$ vs $178.8 \pm 5.6 \mathrm{mg} / \mathrm{dL} ; 112.9 \pm 10.1$ vs $120.9 \pm 9.2 \mathrm{mg} / \mathrm{dL} ; .0 .73 \pm 0.18$ vs $0.99 \pm 0.08 \mathrm{mg} / \mathrm{dL}$ and $6.7 \pm 0.85$ and $6.8 \pm 0.90 \mathrm{mg} / \mathrm{dL}$, respectively.

Table 2. Anthropometric and biochemical data of control and hypertensive subjects.

\begin{tabular}{lll}
\hline Total protein mg/dL & $6.7 \pm 0.85$ & $6.8 \pm 0.90^{\mathrm{b}}$ \\
Creatinine mg/dL & $0.73 \pm 0.18$ & $0.99 \pm 0.08^{\mathrm{b}}$ \\
$\begin{array}{l}\text { Random plasma glucose } \\
\mathrm{mg} / \mathrm{dL}\end{array}$ & $112.9 \pm 10.1$ & $120.9 \pm 9.2^{\mathrm{b}}$ \\
Total Cholesterol mg/dL & $166.8 \pm 38.1$ & $178.8 \pm 5.6^{\mathrm{b}}$ \\
DBP mmHg & $77.2 \pm 4.5$ & $94.0 \pm 13.9^{\mathrm{a}}$ \\
SBP mmHg & $115.0 \pm 5.5$ & $150.5 \pm 15.8^{\mathrm{a}}$ \\
BMI & $21.1 \pm 8.5$ & $23.5 \pm 2.4^{\mathrm{b}}$ \\
Age years & $46.2 \pm 5.6$ & $35.3 \pm 7.9$ \\
Gender M/F & $38 / 20$ & $47 / 19$ \\
Sample size & 58 & 66 \\
Subjects & Normotensive & Hypertensive \\
\hline a $\mathrm{p}<0.001$ (SBP and DBP: hypertensive vs normotensive). ${ }^{\mathrm{b}}$ Not significant.
\end{tabular}


Table 3. Genotype distribution of Bgll, Taql and Mbol RFLP of renin gene in both control and hypertensive subjects.

\begin{tabular}{llll}
\hline \multicolumn{4}{l}{ Study subjects } \\
\hline Renin genotypes & All & Normotensive & Hypertensive \\
\hline $\begin{array}{l}\text { BglI genotype } \\
\text { frequency }\end{array}$ & & & \\
$\mathrm{BB}$ & $13.7(17)$ & $12.1(7)$ & $15.2(10)$ \\
$\mathrm{Bb}$ & $37.9(47)$ & $50.0(29)$ & $31.8(21)$ \\
$\mathrm{bb}$ & $48.4(60)$ & $37.9(22)$ & $53.0(35)$ \\
TaqI genotype & & & \\
frequency & & & \\
$\mathrm{TT}$ & $81.5(101)$ & $91.4(53)$ & $77.3(51)$ \\
$\mathrm{Tt}$ & $14.5(18)$ & $8.6(5)$ & $16.7(11)$ \\
$\mathrm{Tt}$ & $4.0(5)$ & 0 & $6.0(4)$ \\
MboI genotype & & & \\
frequency & & & $6.0(4)$ \\
$\mathrm{MM}$ & $4.0(5)$ & 0 & $28.8(19)$ \\
$\mathrm{Mm}$ & $32.3(40)$ & $41.4(24)$ & $65.2(43)$ \\
$\mathrm{Mm}$ & $63.7(79)$ & $58.6(34)$ & \\
\hline
\end{tabular}

Table 4. Distribution of allele frequencies of Bgll, Taql and Mbol renin gene polymorphisms in normotensive and hypertensive subjects.

\begin{tabular}{lccll}
\hline Alleles & & All & \multicolumn{2}{l}{ Normotensive Hypertensive } \\
\hline BglI polymorphism & & & & \\
& B-allele & 0.33 & 0.37 & 0.31 \\
& b-allele & 0.67 & 0.63 & 0.69 \\
TaqI polymorphism & & & & \\
& T-allele & 0.89 & 0.96 & 0.86 \\
& t-allele & 0.11 & 0.04 & 0.14 \\
MboI polymorphism & & & & \\
& M-allele & 0.20 & 0.21 & 0.20 \\
& m-allele & 0.80 & 0.79 & 0.80 \\
\hline
\end{tabular}

Table 5. Values of SBP and DBP (mean \pm SD) were set apart according to the renin Bgll, Taql and Mbol genotypes. Parentheses in each cell indicate the number of the participants.

\begin{tabular}{|c|c|c|c|c|c|c|}
\hline \multirow[t]{2}{*}{ Genotypes } & \multicolumn{3}{|c|}{ Systolic blood pressure } & \multicolumn{3}{|c|}{ Diastolic blood pressure } \\
\hline & NT & HT & All & NT & HT & All \\
\hline \multicolumn{7}{|c|}{ BglI polymorphism } \\
\hline $\mathrm{BB}$ & $120.25 \pm 5.73(7)$ & $145 \pm 12.9(10)$ & $134.0 \pm 15.65(17)$ & $78.0 \pm 2.94(7)$ & $92.5 \pm 10.41(10)$ & $86.05 \pm 10.11(17)$ \\
\hline $\mathrm{Bb}$ & $120.7 \pm 7.36(29)$ & $163.33 \pm 8.16(21)$ & $135.32 \pm 8.2(50)$ & $77.0 \pm 5.0(29)$ & $105.0 \pm 6.0(21)$ & $88.64 \pm 3.39(50)$ \\
\hline $\mathrm{bb}$ & $151.67 \pm 12.5(22)$ & $116.0 \pm 11.32(35)$ & $144.79 \pm 7.96(57)$ & $76.67 \pm 4.57(22)$ & $101.33 \pm 8.95(35)$ & $92.07 \pm 4.09(57)$ \\
\hline \multicolumn{7}{|c|}{ TaqI polymorphism } \\
\hline TT & $117.95 \pm 7.1(53)$ & $155.91 \pm 15.85(51)$ & $117.95 \pm 20.99(104)$ & $76.86 \pm 3.53(53)$ & $102.0 \pm 13.54(51)$ & $76.86 \pm 13.61(104)$ \\
\hline $\mathrm{Tt}$ & $119.0 \pm 12.72(5)$ & $148.57 \pm 14.63(11)$ & $142.57 \pm 20.19(16)$ & $75.5 \pm 6.36(5)$ & $95.0 \pm 12.91(11)$ & $93.71 \pm 13.78(16)$ \\
\hline $\mathrm{Tt}$ & 0 & $151.67 \pm 10.41(4)$ & $151.67 \pm 10.41(4)$ & 0 & $103.33 \pm 6.66(4)$ & $103.33 \pm 6.66(4)$ \\
\hline \multicolumn{7}{|c|}{ MboI polymorphism } \\
\hline $\mathrm{MM}$ & 0 & $146.33 \pm 11.80(4)$ & $146.33 \pm 11.80(4)$ & 0 & $95.67 \pm 5.1(4)$ & $95.67 \pm 5.1(4)$ \\
\hline $\mathrm{Mm}$ & $120.67 \pm 8.96(24)$ & $146.67 \pm 20.82(19)$ & $120.67 \pm 8.96(43)$ & $77.0 \pm 6.1(24)$ & $98.33 \pm 14.43$ (19) & $77.0 \pm 6.08(43)$ \\
\hline $\mathrm{mm}$ & $122.0 \pm 6.24(34)$ & $143.33 \pm 5.77(43)$ & $120.0 \pm 6.24(77)$ & $78.0 \pm 1.73(34)$ & $94.33 \pm 1.15(43)$ & $78.0 \pm 1.73(77)$ \\
\hline
\end{tabular}

NT: Normotensive and HT: Hypertensive subjects.

\section{Discussion}

The screening of variations within the renin gene to assess its linkage with high blood pressure i.e., hypertension was the main objective of the present study. The linkage and sib-pair linkage analysis and association studies have laid the ground work to evaluate the effects of genetic variations in renin gene in human population. However, the results of various sib-pair analyses have been inconsistent in clearly linking nucleotide variations of renin gene as the appropriate cause of hypertension [27-29]. Numerous studies in different ethnic population have focused attention on renin intronic polymorphisms, such as HindIII, BglI and MboI as well as the promoter TaqI polymorphism that varied greatly among different reports [13-20, 30-38]. To our knowledge this is the first study carried out to determine the renin gene restriction fragment length polymorphism among Bangladeshi hypertensive and normotensive subjects. This study revealed that homozygosity (both for common and rare alleles) was common in renin gene regarding $\mathrm{Bgl \textrm {I }}\left(\mathrm{bb}=48.4 \%, \mathrm{Bb}=37.9 \%, \mathrm{BB}=13.7 \%, \chi^{2}\right.$ $=1.91, \mathrm{P}>0.05), \mathrm{Taq} \mathrm{I}\left(\mathrm{TT}=81.5 \%, \mathrm{Tt}=14.5 \%, \mathrm{tt}=4.0 \%, \chi^{2}\right.$ 
$=7.50, \mathrm{P}<0.01)$ and $\mathrm{MboI}(\mathrm{mm}=63.7 \%, \mathrm{Mm}=32.3 \%$, $\left.\mathrm{MM}=4.0 \%, \chi^{2}=0.00, \mathrm{P}>0.05\right)$ polymorphisms among total population (Table 3).

Renin gene locus has been studied for essential hypertension using hypertensive rat models $(12,39]$. In human, the association of $B g l$ I dimorphism in renin gene with hypertension in different populations [15, $20,32]$ has been demonstrated, while others fail to establish such association $[14,30]$. On the other hand, Berge and Berg [31] in a study with Norwegian population demonstrated that $B g l \mathrm{I}$ restriction fragment length polymorphism at the renin locus has neither the "level gene" nor "variability gene" effects on blood pressure. Allelic frequency of BglI renin gene polymorphism in present study subjects (either hypertensive or normotensive) showed that $\mathrm{b}$ allele (rare homozygous) was more prevalent compare to B allele (common homozygous) whereas, a meta-analysis of the case-control association studies with four populations demonstrated that renin gene $B g l \mathrm{I}$ B allele is associated with increased risk of developing essential hypertension [17].

TaqI polymorphism is located in 4063 bases upstream of renin gene and change in single nucleotide may prevent its expression. The presence of a TaqI site in renin gene has been reported to be correlated with lower values of plasma renin activity and higher diastolic blood pressure [32]. Studies [19, 38] proposed a strong association of TaqI polymorphism with hypertension and found that the frequencies of TaqI $t$ allele were almost similar in two groups of Chinese study population which were lower compared to Caucasian European (13.75\%) and Afro-Caribbean (28.45\%) populations $[40,41]$. In current study, the frequency of $\mathrm{T}$ allele was higher than the frequency of $t$ allele and showed homozygosity (TT) as genotype frequency follows the Hardy-Weinberg equilibrium law. Our findings revealed that genotype frequency with rare homozygous (tt genotype) were lacking in healthy subjects who had normal blood pressure compared to those $6.0 \%$ hypertensive subjects.

The distribution of $B g l \mathrm{I}$ and $\mathrm{TaqI}$ renin gene frequencies in the normotensive subjects were found to be in agreement with Hardy-Weinberg equilibrium, which indicated suitable selection of study subjects. Ahmad et al. [20] and Frossard et al. [32] also found that the genotype frequencies of their normotensive subjects followed Hardy-Weinberg equilibrium. On the other hand, the genotype distribution in the hypertensive group of the present study did not follow the equilibrium rule. This disequilibrium in this group of study subjects could be due to the presence of other loci that might be close to either of the BglI or TaqI polymorphic sites which have strong influence on blood pressure and are strongly linked to the these sites. Also, it should be considered that being a part of the intronic sequences these sequences might be very unlikely to have produced such a strong effect by their own. In the light of this groundwork, it could be portrayed that associations of genotype frequencies of BglI and TaqI renin gene polymorphisms with SBP and DBP are lacking in the study subjects (Table 5) though the SBP and DBP varied significantly between normotensive and hypertensive subjects (Table 2).

Due to its location within intron 9, MboI RFLP probably does not represent a functional genetic variation. However, genetic variation in this region showed strong positive association with hypertension in different population groups [31,33] while others did not find such association [36, 42]. Okura et al. [37] were the first to show a positive association between renin gene $M b o$ I RFLP and essential hypertension in Japanese population using linkage disequilibrium with this site or in a nearby gene. One of the possible explanations for this variable pattern of association could be the involvement of more than one gene, with none of the involved genes having a strong influence or penetrance, as is expected for a complex polygenic disorder. Frossard et al. [31, 32] reported frequencies of 0.64 and 0.36 for the $M b o I ~ G$ and MboI A alleles in normotensive subjects, whereas the allele frequencies in the hypertensive group were 0.49 and 0.51 , respectively. In the present study, the allelic frequencies were 0.79 and 0.80 for $\mathrm{m}$ and 0.21 and 0.20 for $\mathrm{M}$ alleles, respectively for normotensive and hypertensive subjects. In this case, the $\mathrm{Mbol}$ genotype frequencies of hypertensive subjects followed the Hardy-Weinberg Equilibrium law while the normotensive subjects did not follow this rule. Interestingly, the observed frequency of MM genotypes (homozygous for common allele at each locus) were lacking among the normotensive subjects enrolled in the present study while $6.0 \%$ of the hypertensive subjects showed such genotypic frequency. Moreover, we did not find any association between the $\mathrm{Mbo}$ I genotypic frequencies of the normotensive and hypertensive subjects with their respective SBP and DBP (Table 5).

Genetic profiling of the functional genes not only helps to investigate a specific disease but also to understand the disease propensity within a particular population that may ultimately be of assistance to the clinicians and physicians for prescribing personalized medicine. Brugts et al. in their series of articles [43-46] suggested a broad description of the role of ACE inhibition in the treatment of patients with atherosclerosis. In a substudy of the well-described EUROPA trial with 9454 patients suffering from stable coronary artery disease [47], a genetic analysis was performed 
(PERGENE study). All these data within their limitations serve as substitute for the functional variant which are mostly rare and are not well covered by traditional genome-wide association studies.

Previous study in Bangladeshi hypertensive population demonstrated that among the three DD, II and ID angiotensin converting enzyme (ACE) gene variants, the DD genotype was associated with the highest value of the mean systolic blood pressure and mean diastolic blood pressure in men, but not in women [48]. Despite the considerable controversy regarding the existence and importance of ethnic differences in genetic effects for complex diseases, it seems evident that genetic markers for proposed gene-disease associations vary in frequency across populations. Thus, it is important to construct a database of polymorphisms related to hypertension in each ethnic group as suggested by Izawa et al. [49]. In humans, elevated blood pressure is associated with increased risk of vascular diseases including myocardial infarction, stroke and coronary artery disease. The variance in blood pressure and its regulation followed by cardiovascular disease susceptibility within populations sharing a common environment indicates that there are genetic as well as cultural determinants of risk [50]. Some ethnic groups may be at particular risk of high blood pressure exposed to the same urban environment suggesting involvement of genetic factors. While, changes in lifestyle predominantly the diet and physical activity play an important role in the growing rates of hypertension leading to cardiovascular related complications in developing countries [50]. The Asian Indians residing in Singapore have three times higher rates of myocardial infarction than that of Chinese population despite exposure to a similar environment [51]. On the other hand, individuals within the same family, may become hypertensive due to different combinations of genes or due to exposure to different environment including life style, dietary habit or lack of physical activity [52]. Thus, it has been suggested that the possible reasons accounting for the controversy regarding ethnic differences are neither only for genetic variations nor for other risk associated factors alone rather due to complex interplay between environment, diet, physical activity and genetic variations [53].

It is indeed a matter of argument regarding the fact that why Bangladeshi people are lacking an association between the renin gene polymorphisms and hypertension in the current study while other Asian people like Chinese, Japanese, and United Arab Emiratis displayed such association. Different studies postulated that South Asians have highest levels of subclinical atherosclerosis than the Chinese [54] and among the South Asians, Bangladeshis have lowest rate of hypertension than Indians and Pakistanis [55]. These studies clearly demonstrate that neither the genetic nor the other associated factors alone play role in initiating hypertension with increased blood pressure along with different cardiovascular associated phenotypic expression in Bangladeshi people compare to other Asian people; even compare to other South Asian Indians and Pakistanis. Interestingly, contrasting results regarding the association of $\mathrm{MboI}$ restriction fragment length polymorphism of renin gene have been reported even in the same Japanese population [36, 37]. Even with the small genetic diversity, Japanese people showed two clusters with different genotypic variations [56-58] which might be the reason of two different $M b o \mathrm{I}$ renin gene polymorphism data $[36,37]$. However, rather than excluding the possibility of Indo-Aryan migration [59], different studies suggest that the genetic affinities of both Indian ancestral parts are the result of multiple gene pools that flows over the course of thousands of years, with Indo-Aryan extension into the subcontinent [60]. Thus, these accumulating data suggest that genetic diversity along with environmental, dietary, cultural as well as genome-wide signals of positive selection from the ancestors might have collectively contributed to the phenotypic diversity in South Asians especially in Bangladeshi people.

The present study has to be taken under consideration within the context of its limitations. It is to mention here that this research work only deals with the association study (irrespective of gender) between blood pressure and the genetic variation of the 3 restriction sites within the renin gene and near its promoter sequence. However, multivariate analyses using age and gender as independent variable respectively also revealed lack of association of renin gene polymorphism with blood pressure. Here, we report that, Bangladeshi hypertensive subjects did not show any distinct pattern of renin gene polymorphisms compared to their healthy counterparts with regard to their genotypic and allelic frequencies, though the rare homozygous in case of TaqI (tt genotype) and common homozygous in case of $\mathrm{MboI}$ (MM genotype) are lacking in the normotensive subjects.

\section{Acknowledgement}

This study was supported by the grant provided by Ministry of Science and Technology, Government of the People's Republic of Bangladesh, University Grants Commission, Bangladesh and Biotechnology Research Center, University of Dhaka. Authors would also like to express their sincere thanks and heartfelt gratitude to Professors Dr. Mustafizur Rahman, Dr. 
Haseena Khan and Dr. Zeba Islam Seraj for their intellectual and technical supports during this research work.

\section{Conflict of Interests}

The authors have declared no conflict of interests.

\section{References}

1. Tanira MO, Al Balushi KA. Genetic variations related to hypertension: a review. J Hum Hypertens. 2005; 19: 7-19.

2. Oparil S, Haber E. The renin-angiotensin system (first of two parts). N Engl J Med. 1974; 291: 389-401.

3. Corvol P, Jeunemaitre X, Charru A, Kotelevtsev Y, Soubrier F. Role of the renin-angiotensin system in blood pressure regulation and in human hypertension: new insights from molecular genetics. Rec Prog Horm Res. 1995; 50: 287-308.

4. Peters J. Molecular basis of human hypertension: the role of angiotensin. Baill Clin Endocrin Metab. 1995; 9: 657-678.

5. Tamura K, Umemura S, Fukamizu A, Ishii M, Murakami K. Recent advances in the study of renin and angiotensinogen genes: from molecules to the whole body. Hypertens Res. 1995; 18: 7-18.

6. Thadhani R, Camargo CA, Stampfer MJ, Curhan GC, Willett WC, Rimm EB. Prospective study of moderate alcohol consumption and risk of hypertension in young women. Arch Intern Med. 2002; 162:569-574.

7. Pi-Sunyer FX. Health implications of obesity. Am J Clin Nutr. 1991; 53:1595S-1603S.

8. He J, Whelton PK: Epidemiology and prevalence of hypertension. Med Clin North Am. 1997; 81: 1077-1097.

9. Kobori H, Ozawa Y, Suzaki Y, Prieto-Carrasquero MC, Nishiyama A, Shoji T, Cohen EP, Navar LG. Young Scholars Award Lecture: Intratubular angiotensinogen in hypertension and kidney diseases. Am J Hypertens. 2006; 19: 541-50.

10. Oparil S, Haber E. () The renin-angiotensin system (second of two parts). N Engl J Med. 1974; 291: 446-457.

11. Carretero OA, Oparil S. Essential hypertension. Part I: definition and etiology. Circulation. 2000; 101: 329-335.

12. Rapp JP, Dene H, Wang SM. Restriction fragment length polymorphisms for the renin gene in Dahl rats. J Hypertens. 1989; 7: 121-126.

13. Matsubara M. Genetic determination of human essential hypertension. Tohoku J Exp Med. 2000; 192: 19-33.

14. Naftilan AJ, Williams R, Burt D, Paul M, Pratt RE, Hobart P, Chirgwin J, Dzau VJ. A lack of genetic linkage of renin gene restriction fragment length polymorphisms with human hypertension. Hypertension. 1989; 14: 614-618.

15. Frossard PM, Lestringant GG, Malloy MJ, Kane JP. Human renin gene BglI dimorphism associated with hypertension in two independent populations. Clin Genet. 1999; 56: 428-433.

16. Morris BJ, Griffiths LR. Frequency in hypertensives of alleles for a RFLP associated with the renin gene. Biochem Biophys Res Commun. 1988; 150: 219-224.

17. Niu W, Qi Y, Guo S, Gao P, Zhu D. Association of renin Bgll polymphism with essential hypertension: a meta-analysis involving 1811 cases and 1626 controls. Clin Exp Hypertension. 2010; 32: 431-438.

18. Chang YP, Zhu X, Yan D, Weder A, Cooper R, Luke A, Kan D, Chakravarti A. Associations between hypertension and genes in the renin-angiotensin system. Hypertension. 2003; 41:1027-34.

19. Qi Y, Niu W, Cen W, Cui C, Zhuoma C, Zhuang L, Cai D, Li G, Zhou W, Hou S, Qiu C. Strong association of the renin TaqI polymorphism with essential hypertension in Chinese Han and Tibetan populations. J Hum Hypertens. 2007; 21: 907-910.

20. Ahmad U, Saleheen D, Bokhari A, Frossard PM. Strong association of a renin intronic dimorphism with essential hypertension. Hypertens Res. 2005; 28: 339-344.

21. Perkovic V, Huxley R, Wu Y, Prabhakaran D, MacMahon S. The Burden of Blood Pressure-Related Disease: A Neglected Priority for Global Health. Hypertension. 2007; 50: 991-997.

22. Zaman MM, Yoshiike N, Rouf MA, Syeed MH, Khan MR, Haque S, Mahtab H, Tanaka H. Cardiovascular risk factors: distribution and prevalence in a rural population of Bangladesh. J Cardiovasc Risk. 2001; 8: 103-108.

23. Sayeed MA, Banu A, Haq JA, Khanam PA, Mahtab H, Azad Khan AK Prevalence of hypertension in Bangladesh: effect of socioeconomic risk factor on difference between rural and urban community. Bangladesh Med Res Counc Bull. 2002; 28: 7-18.

24. Miyazaki H, Fukamizu A, Hirose S, Hayashi T, Hori H, Ohkubo H, Nakanishi S, Murakami K. Structure of the human renin gene. Proc Natl Acad Sci USA. 1984; 81: 5999-6003

25. [Internet] Iranpur MV, Esmailizadeh AK. Rapid Extraction of High Quality DNA from Whole Blood Stored at $4^{\circ} \mathrm{C}$ for Long Period. http://www.protocol-online.org/cgi-bin/prot/page.cgi?g=print_page/ 4175.html.

26. Rodriguez S, Gaunt TR, Ian NMD. Hardy-Weinberg Equilibrium Testing of Biological Ascertainment for Mendelian Randomization Studies. Am J Epidemiol. 2009; 169: 505-514.

27. Jeunemaitre X, Rigat B, Charru A, Houot AM, Soubrier F, Corvol P. Sib pair linkage analysis of renin gene haplotypes in human hypertension. Hum Genet. 1992; 88: 301-306.

28. Niu T, Xu X, Cordell HJ, Cordell HJ, Rogus J, Zhou Y, Fang Z, Lindpaintner $\mathrm{K}$. Linkage analysis of candidate genes and gene-gene interactions in Chinese hypertensive sib pairs. Hypertension. 1999; 33: 1332-1337.

29. Caulfield M, Lavender P, Newell-Price J, Farrall M, Kamdar S, Daniel H, Lawson M, De Freitas P, Fogarty P, and Clark A J. Linkage of the angiotensinogen gene to essential hypertension. N Engl J Med. 1994; 330: 1629-1633.

30. Berge KE, Berg K. No effect of a BglI polymorphism at the renin (REN) locus on blood pressure level or variability. Clin Genet. 1994; 46: 436-438.

31. Frossard PM, Kane JP, Malloy MJ, Bener A. Renin gene MboI dimorphism is a discriminator for hypertension in hyperlipidaemic subjects. Hypertens Res. 1999; 22: 285-289.

32. Frossard PM, Lestringant GG, Hughes PF. Correlations between RFLPs of the human renin gene locus and clinical variables of blood pressure regulation. Biogenic Amines. 1995; 11: 313-324.

33. Frossard PM, Lestringant GG, Elshahat YI, John A, Obineche EN. An $\mathrm{MboI}$ two-allele polymorphism may implicate the human renin gene in primary hypertension. Hypertens Res. 1998; 21: 221-225.

34. Frossard PM, Malloy MJ, Lestringant GG, Kane JP. Haplotypes of the human renin gene associated with essential hypertension and stroke. J Hum Hypertens. 2001; 15: 49-55.

35. West MJ, Summers KM, Burstow DJ, Wong KK, Huggard PR. Renin and angiotensin-converting enzyme genotypes in patients with essential hypertension and left ventricular hypertrophy. Clin Exp Pharmacol Physiol. 1994; 21: 207-210.

36. Fu Y, Katsuya T, Asai T, Fukuda M, Inamoto N, Iwashima Y, Sugimoto $\mathrm{K}$, Rakugi H, Higaki J, Ogihara T. Lack of correlation between MboI restriction fragment length polymorphism of renin gene and essential hypertension in Japanese. Hypertens Res. 2001; 24: 295-298.

37. Okura T, Kitami Y, Wakamiya R, Iwata T, Hiwada K. Renin gene restriction fragment length polymorphisms in a Japanese family with a high incidence of essential hypertension. Clin Exp Pharmacol Physiol Suppl. 1992; 20: 17-19.

38. Niu W, Qi Y, Hou S, Zhai X, Zhou W, Qiu C. Haplotype-based association of the renin-angiotensin-aldosterone system genes polymorphisms with essential hypertension among Han Chinese: the Fangshan study. J Hypertens. 2009; 27: 1384-1391.

39. Mullins JJ, Peters J, Ganten D. Fulminant hypertension in transgenic rats harbouring the mouse Ren-2 gene. Nature. 1990; 344: 541-544.

40. Deinum J, Tarnow L, van Gool JM, de Bruin RA, Derkx FH, Schalekamp MA, Parving HH. Plasma renin and prorenin and renin gene variation in patients with insulin-dependent diabetes mellitus and nephropathy. Nephrol Dial Transplant. 1999; 14: 1904-1911.

41. Barley J, Carter ND, Cruickshank JK, Jeffery S, Smith A, Charlett A, Webb DJ. Renin and atrial natriuretic peptide restriction fragment length polymorphisms: association with ethnicity and blood pressure. J Hypertens. 1991; 9: 993-996.

42. Ramachandran V, Ismail P, Stanslas J, Shamsudin N. Analysis of renin-angiotensin aldosterone system gene polymorphisms in malaysian essential hypertensive and type 2 diabetic subjects. Cardiovascular Diabetology. 2009; 8: 11 .

43. Brugts JJ, de Maat MPM, Danser AHJ, Boersma E, Simoons ML. Individualised therapy of $\mathrm{ACE}$ inhibitors in stable coronary artery disease: overview of the primary results of the PERindopril GENEtic association study. Neth Heart J. 2012; 20: 24-32.

44. Brugts JJ, de Maat MP, Boersma E, Witteman JC, van Duijn C, Uitterlinden AG, Bertrand M, Remme W, Fox K, Ferrari R, Danser AH, Simoons ML; EUROPA-PERGENE investigators. The rationale and design of the perindopril genetic association study (pergene): a pharmacogenetic analysis of angiotensin-converting enzyme inhibitor therapy in patients 
with stable coronary artery disease. Cardiovasc Drugs Ther. 2009; 23: $171-181$.

45. Brugts JJ, Isaacs A, Boersma E, van Duijn CM, Uitterlinden AG, Remme W, Bertrand M, Ninomiya T, Ceconi C, Chalmers J, MacMahon S, Fox K, Ferrari R, Witteman JC, Danser AH, Simoons ML, de Maat MP. Genetic determinants of treatment benefit of the angiotensin-converting enzyme-inhibitor perindopril in patients with stable coronary artery disease. Eur Heart J. 2010; 31: 1854-1864.

46. Brugts JJ, Boersma E, Simoons ML. Tailored therapy of ACE inhibitors in stable coronary artery disease: pharmacogenetic profiling of treatment benefit. Pharmacogenomics. 2010; 11: 1115-1126.

47. Fox KM. Efficacy of perindopril in reduction of cardiovascular events among patients with stable coronary artery disease: randomised, double-blind, placebo-controlled, multicentre trial (the Europa study). Lancet. 2003 ; 362: 782-788.

48. Morshed M, Khan H, Akhteruzzaman S. Association between angiotensin I-converting enzyme gene polymorphism and hypertension in selected individuals of the Bangladeshi population. Journal of Biochemistry and Molecular Biology. 2002; 35:251-254.

49. Izawa H, Yamada $\mathrm{Y}$, Okada T, Tanaka M, Hirayama H, Yokota M. Prediction of genetic risk for hypertension. Hypertension. 2003; 41: 1035-1040.

50. Yusuf S, Reddy S, Ounpuu S, Anand S. Global burden of cardiovascular diseases: part I: general considerations, the epidemiologic transition, risk factors, and impact of urbanization. Circulation. 2001; 104: 2746-2753.

51. Tai SE, Tan CE. Interaction between genetic and dietary factors affecting cardiovascular risk. Asia Pac J Clin Nutr. 2005; 14: 72-77.

52. Mehta SK, Super DM, Anderson RL, Harcar-Sevcik RA, Babjak M, Liu X, Bahler RC. Parental hypertension and cardiac alterations in normotensive children and adolescents. Am Heart J. 1996; 131: 81-8.

53. Svetkey LP, Moore TJ, Simons-Morton DG, Appel LJ, Bray GA, Sacks FM, Ard JD, Mortensen RM, Mitchell SR, Contin PR, Kesari M. Angiotensinogen genotype and blood pressure response in the Dietary Approaches to Stop Hypertension (DASH) study. J Hypertens. 2001; 19: 1949-1956.

54. Anand SS, Yusuf S, Vuksan V, Devanesen S, Teo KK, Montague PA, Kelemen L, Yi C, Lonn E, Gerstein H, Hegele RA, McQueen M. Differences in risk factors, atherosclerosis, and cardiovascular disease between ethnic groups in Canada: the Study of Health Assessment and Risk in Ethnic groups (SHARE). Lancet. 2000; 356: 279-84.

55. Bhopal R, Unwin N, White M, Yallop J, Walker L, Alberti KG, Harland J, Patel S, Ahmad N, Turner C, Watson B, Kaur D, Kulkarni A, Laker M, Tavridou A. Heterogeneity of coronary heart disease risk factors in Indian, Pakistani, Bangladeshi, and European origin populations: cross sectional study. Br Med J. 1999; 319: 215-220.

56. Haga H, Yamada R, Ohnishi Y, Nakamura Y, Tanaka T. Gene-based SNP discovery as part of the Japanese Millennium Genome Project: identification of 190,562 genetic variations in the human genome. Single-nucleotide polymorphism. J Hum Genet. 2002; 47: 605-610.

57. Hammer MF, Karafet TM, Park H, Omoto K, Harihara S, Stoneking M, Horai S. Dual origins of the Japanese: common ground for hunter-gatherer and farmer Y chromosomes. J Hum Genet. 2006; 51: 47-58.

58. Yamaguchi-Kabata Y, Nakazono K, Takahashi A, Saito S, Hosono N, Kubo M, Nakamura Y, Kamatani N. Japanese population structure, based on SNP genotypes from 7003 individuals compared to other ethnic groups: effects on population-based association studies. Am J Hum Genet. 2008; 83: 445-456.

59. Metspalu M, Romero IG, Yunusbayev B, Chaubey G, Mallick CB, Hudjashov G, Nelis M, Mägi R, Metspalu E, Remm M, Pitchappan R, Singh L, Thangaraj K, Villems R, Kivisild T. Shared and unique components of human population structure and genome-wide signals of positive selection in South Asia. Am J Hum Genet. 2011; 89: 731-744.

60. HUGO Pan-Asian SNP Consortium, Abdulla MA, Ahmed I, Assawamakin A, Bhak J, Brahmachari SK, Calacal GC, Chaurasia A, Chen $\mathrm{CH}$, Chen J, Chen YT, Chu J, Cutiongco-de la Paz EM, De Ungria MC, Delfin FC, Edo J, Fuchareon S, Ghang H, Gojobori T, Han J, Ho SF, Hoh BP, Huang W, Inoko H, Jha P, Jinam TA, Jin L, Jung J, Kangwanpong D, Kampuansai J, Kennedy GC, Khurana P, Kim HL, Kim K, Kim S, Kim WY, Kimm K, Kimura R, Koike T, Kulawonganunchai S, Kumar V, Lai PS, Lee JY, Lee S, Liu ET, Majumder PP, Mandapati KK, Marzuki S, Mitchell W, Mukerji M, Naritomi K, Ngamphiw C, Niikawa N, Nishida N, Oh B, Oh S, Ohashi J, Oka A, Ong R, Padilla CD, Palittapongarnpim P, Perdigon HB, Phipps ME, Png E, Sakaki Y, Salvador JM, Sandraling Y, Scaria V, Seielstad M, Sidek MR, Sinha A, Srikummool M, Sudoyo H, Sugano S, Suryadi H, Suzuki Y, Tabbada KA, Tan A, Tokunaga K, Tongsima S, Villamor LP, Wang E, Wang Y, Wang H, Wu JY, Xiao H, Xu
S, Yang JO, Shugart YY, Yoo HS, Yuan W, Zhao G, Zilfalil BA. Indian Genome Variation Consortium. Mapping human genetic diversity in Asia. Science. 2009; 326: 1541-1545. 